\title{
New Chironomidae (Diptera) with elongate proboscises from the Late Jurassic of Mongolia
}

\author{
Elena D. Lukashevich ${ }^{1, \dagger}$, Andrey A. Przhiboro ${ }^{2, \ddagger}$ \\ I Borissiak Paleontological Institute, Russian Academy of Sciences, Moscow, Russia 2 Zoological Institute, Rus- \\ sian Academy of Sciences, St.Petersburg, Russia \\ † urn:lsid:zoobank.org:author:0141038E-4CB5-471E-98C0-14355F71DD2C \\ ¥urn:lsid:zoobank.org:author:BC9F4FE2-D4AA-44DF-A11F-9321760CEC11 \\ Corresponding author: Elena D. Lukashevich (elukashevich@hotmail.com)
}

Academic editor: D. Shcherbakov | Received 16 May 2011 | Accepted 1 July 2011 | Published 24 September 2011

urn:lsid:zoobank.org:pub:126C8645-3A4E-4C51-98D3-2ECB5F9ED5A1

Citation: Lukashevich ED, Przhiboro AA (2011) New Chironomidae (Diptera) with elongate proboscises from the Late Jurassic of Mongolia. In: Shcherbakov DE, Engel MS, Sharkey MJ (Eds) Advances in the Systematics of Fossil and Modern Insects: Honouring Alexandr Rasnitsyn. ZooKeys 130: 307-322. doi: 10.3897/zookeys.130.1555

\begin{abstract}
Four new species of Chironomidae with well-developed elongate proboscises are described from a Late Jurassic site Shar Teg in SW Mongolia. These are named Cretaenne rasnicyni sp. n., Podonomius blepharis sp. n., P. macromastix sp. n., ? P. robustus sp. n.
\end{abstract}

\section{Keywords}

Diptera, Chironomidae, fossil, proboscis, feeding, new species, Mongolia, Late Jurassic

\section{Introduction}

The present paper continues a series of articles with descriptions of Diptera from the Late Jurassic Shar Teg site (e.g. Kalugina 1992, Lukashevich 2009). The Upper Jurassic lacustrine deposits of Shar Teg Beds outcrop at Ulan Malgait Mt., 4-5 km west of Shar Teg Mt., $100 \mathrm{~km}$ ESE of Altai Somon, Gobi-Altai Aimag, SW Mongolia. The fossil assemblage of Shar Teg includes a diverse and abundant complex of flora and fauna (Gubin and Sinitza 1996). 
About 600 identifiable dipteran fossils are known among 3000 fossil insects collected at Shar Teg. Up to now, members of two culicomorph families are described from this locality, Dixidae (Lukashevich 1996) and Chaoboridae (Lukashevich, in press). The representatives of Culicidae and Ceratopogonidae (unknown in Jurassic beds), Simuliidae (rare Jurassic finds) and Thaumaleidae (one fossil from Transbaikalia, $\mathrm{J}_{3}-\mathrm{K}_{1}$ ) are not found in Shar Teg.

The Mesozoic records of Chironomidae are numerous, and usually it is the aquatic immatures that are dominant (Kalugina and Kovalev 1985, Jell and Duncan 1986, Kalugina 1993). In Shar Teg, the Chironomidae is one of the most numerically abundant groups: about fifty impressions of adults and twenty pupae and empty pupal exuviae have been collected (undoubted larvae are absent), but due to poor or fragmentary preservation most adults have not been determined even to subfamily. Therefore only several specimens are described herein (pupae will be described later). This chironomid assemblage "very much resembles the stranded corpses of adults and pupae left beside a falling stream, or on the wave swept shore of a lake" (P.S. Cranston, pers. comm.).

The adults of nearly all extant chironomid midges have reduced mouthparts and so their common name is "non-biting midges". However the presence of toothed mandibles in a chironomid midge was recognized first by Downes and Colless (1967), and now they are described in two recent genera of Podonominae, Archaeochlus Brundin, 1966 and Austrochlus Cranston, 2002 known only from Australia and southern Africa (Cranston et al. 1987, Cranston et al. 2002). Their mandibles closely resemble those of many insectivorous predatory Ceratopogonidae such as Probezzia Kieffer, 1906; however, until females are observed feeding, the question will remain unresolved. A culicomorphan of uncertain affinity with a long proboscis is described from the Upper Triassic Cow Branch Formation (Late Carnian) of Virginia, USA (Blagoderov et al. 2007). Recently, functional mandibulate mouthparts are reported in females (and sometimes even in males) of several extinct genera of Chironomidae from Early Cretaceous Lebanese amber (Azar et al. 2008).

New chironomids with biting mouthparts from Shar Teg are described herein. These fossils are housed in the Borissiak Paleontological Institute, Russian Academy of Sciences, Moscow (PIN). Photographs were made using a Leica MZ 9.5 stereomicroscope with a Leica DFC420 digital camera, with further correction using Adobe Photoshop ${ }^{\circ}$ CS 9.0 software. Measurements were made with an ocular micrometer in a Leica stereomicroscope. Morphological terminology and measurements mainly follow Sæther (1980). Vein nomenclature is after Wootton and Ennos (1989), followed by Shcherbakov et al (1995): the chironomid veins traditionally named $\mathrm{MCu}$ and An are in fact $\mathrm{bM}_{3+4}(t b$ of Kalugina) and CuP, respectively. For further details regarding the mentioned fossil localities, see Rasnitsyn and Quicke (2002). 


\section{Systematics}

\section{Family Chironomidae Newman, 1834 \\ Subfamily ?Aenneinae Ansorge, 1999}

\section{Genus Cretaenne Azar, Veltz \& Nel, 2008}

http://species-id.net/wiki/Cretaenne

Cretaenne Azar et al. 2008: 688. Type species Cretaenne kobeyssii Azar et al. 2008: 689.

The genus was established based on two species from Early Cretaceous Lebanese amber. The specimens under description are assigned to this genus due to functional blade-like laciniae and mandibles in females, postnotum with a longitudinal groove, reduced hind tibial comb, and peculiarities of wing venation (vein $\mathrm{C}$ long and reaching wing tip; Sc not terminating in wing margin; $R_{2}$ present; cell between divergent $R_{2+3}$ and $\mathrm{R}_{4+5}$ very broad; $\mathrm{R}_{4+5}$ almost straight; $\mathrm{bM}_{3+4}$ present; $r-m, \mathrm{bM}_{3+4}$ and $m-c u$ aligned; $m$-cu connecting $\mathrm{CuA}$ proximal to $r-m)$. In the new species, tibial spurs are probably present; however, their structure remains unclear due to the state of preservation. The structure of claws is important for the determination of Lebanese species, but claws are not visible in the Mongolian specimens as well as the details of chaetotaxy (e.g., on pedicel) and therefore not mentioned in the description.

\section{Cretaenne rasnicyni sp. $\mathrm{n}$.}

urn:Isid:zoobank.org:act:1F783221-19EE-43C3-8764-45B6B34E0CB4

http://species-id.net/wiki/Cretaenne_rasnicyni

Etymology. Named in honour of an outstanding Russian palaeoentomologist Dr A.P. Rasnitsyn.

Material examined. Holotype: part and counterpart of well-preserved female PIN 4270/2379 \pm , SW Mongolia, Shar Teg (443/1); Late Jurassic. Paratypes: impressions of two females PIN 4270/2367 \pm , 2459, from the same outcrop.

Diagnosis. The new species is distinguished from both known species of Cretaenne by the longer proboscis (more than half of the head height and about twice the clypeus height) and the longer Rs stem.

Description. Female. Measurements (mm): Total length 2.1-2.7 (holotype 2.3); thorax length ca. 0.8, width ca. 0.4; wing length 2.1-2.3 (holotype 2.1); abdomen length 1.35-1.8 (holotype 1.5). Total length / wing length 1.1.

Holotype (Figs 1a-d, 2b-c). Coloration. Thorax dark, abdomen and legs lighter, at least some legs with slightly darker apices of femora and tibiae. Head ca. $550 \mu \mathrm{m}$ wide, ca. $400 \mu \mathrm{m}$ high to lower eye margin. Scape ca. $100 \mu \mathrm{m}$, pedicel ca. $30 \mu \mathrm{m}$ in diameter. Clypeus ca. $200 \mu \mathrm{m}$ wide, ca. $250 \mu \mathrm{m}$ high. Proboscis with visible part ca. $350 \mu \mathrm{m}$ long 
(possibly, without apex), tapering, sclerotized. Thorax. Postnotum wider than long, ca. $200 \mu \mathrm{m}$ long, possibly with longitudinal median groove. Wing longer than abdomen, Sc clearly up to Rs level, thinning distally, possibly not reaching $\mathrm{C}$ (apical part of Sc not discernible). Vein $\mathrm{C}$ and radial veins strong, coloured $\left(\mathrm{R}_{2+3}\right.$ thinner then others), as well as proximal sections of $\mathrm{M}$ and $\mathrm{CuA}, r-m$ and $\mathrm{bM}_{3+4}$. Long stem Rs subequal to $r-m ; \mathrm{R}_{4+5} 8-9$ times as long as $\mathrm{R}_{2} ; \mathrm{R}_{2}$ distinctly longer than $\mathrm{dR}_{1}$. VR 1.1. Legs (lengths not measurable). Femora (mid-and hind) widened to apex, maximum $120 \mu \mathrm{m}$ wide, with thin sclerotized ridge ventrally near apex. Tibiae (mid- and hind) apically 80-100 $\mu \mathrm{m}$ wide. Tarsi not preserved. Abdomen. Abdominal segments II-V: ca. $200 \mu \mathrm{m}$ long, 500-600 $\mu \mathrm{m}$ wide. Three large subequal oval sclerotized spermathecae 140-150 $\mu \mathrm{m}$ long, ca. $100 \mu \mathrm{m}$ wide, with necks (probably, short). Gonapophysis IX distinctly visible, sclerotized, with notum ca. $200 \mu \mathrm{m}$ long, $15 \mu \mathrm{m}$ wide at anterior end, with rami ca. $60 \mu \mathrm{m}$ long. Probable gonocoxites VIII (gonacoxapodemes?) visible as moderately sclerotized small oval lobes near posterior end of notum. Cerci short, hardly visible.

Paratypes (Figs 1e-h, 2a). Visible characters as in holotype, with following additions. Head preserved only in PIN 4270/2367, $650 \mu \mathrm{m}$ wide, $850 \mu \mathrm{m}$ high with proboscis, ca. $400 \mu \mathrm{m}$ high to lower eye margin. Eyes with medially narrowing dorsomedial extension, well separated by $60 \mu \mathrm{m}$. Coronal triangle ca. $130 \mu \mathrm{m}$ high, ca. $100 \mu \mathrm{m}$ wide; coronal suture clear, probably pair of poorly visible ocelli (ca. $30 \mu \mathrm{m}$ in diameter) adjoining lower part ventrally to eye dorsomedial extension. Scape ca. 100 $\mu \mathrm{m}$, pedicel ca. $40 \mu \mathrm{m}$ in diameter. Flagellomeres (five distinctly visible lateral to eye margin) short-oval, 50-70 $\mu \mathrm{m}$ long, 30-40 $\mu \mathrm{m}$ wide. Clypeus ca. $200 \mu \mathrm{m}$ wide, ca. $300 \mu \mathrm{m}$ high. Proboscis ca. $550 \mu \mathrm{m}$ long, sclerotized, stylet-like, pointed, with bladelike tapered laciniae and mandibles, labrum apically more sclerotized. Palpi poorly visible, looking widened (ca. $70 \mu \mathrm{m}$ in distal parts); visible parts of palpi reaching about $4 / 5$ of proboscis. Thorax. Scutum weakly, evenly convex; anterior part ca. 300 $\mu \mathrm{m}$ wide. Antepronotals narrowed medially. Scutellum ca. $120 \mu \mathrm{m}$ long; postnotum ca. $200 \mu \mathrm{m}$ long, $300 \mu \mathrm{m}$ wide, with distinct longitudinal median groove. Legs. Measurements $(\mu \mathrm{m}) \cdot \mathrm{p}_{1}\left(\right.$ ?): ti $880, \mathrm{ta}_{1-5} 1200 ; \mathrm{p}_{2}$ : ti 1375, ta $750-850, \mathrm{ta}_{2} \mathrm{ca} .400, \mathrm{ta}_{3-5} \mathrm{ca}$. 700, LR2 0.55; $\mathrm{p}_{3}$ : fe 1000, ti 1450-1500, ta ${ }_{1-5}>1250$. Tibiae 60-100 $\mu \mathrm{m}$ wide near apex. Apices of mid-, hind tibiae with combs of separate spiniform setae (visible only in PIN 4270/2459): midtibia with no less than 3-4 slenderer setae ca. $50 \mu \mathrm{m}$ long, hind tibia with no less than 3 thicker setae, longest ca. $50 \mu \mathrm{m}$. Hind tibia probably with two spurs, 70 and $50 \mu \mathrm{m}$ long.

Remarks. The pattern of the female mouthparts is poorly visible in the holotype and unknown in paratype PIN 4270/2459; paratype PIN 4270/2367 has a well-preserved proboscis and its wing venation is very pale and incomplete; the setae at the tibial apices are distinctly visible only in paratype PIN 4270/2459; in both paratypes the spermathecae are not visible. Hence it is possible that these specimens are not conspecific. However, we suggest that all these specimens belong to the same species due to visible peculiarities of venation (particularly the long Rs stem and $\mathrm{R}_{2}$ position).

The genus Cretaenne was described in the subfamily Aenneinae with reservations, due to the vein Sc not terminating in the wing margin and short Rs stem, as distinct from the 

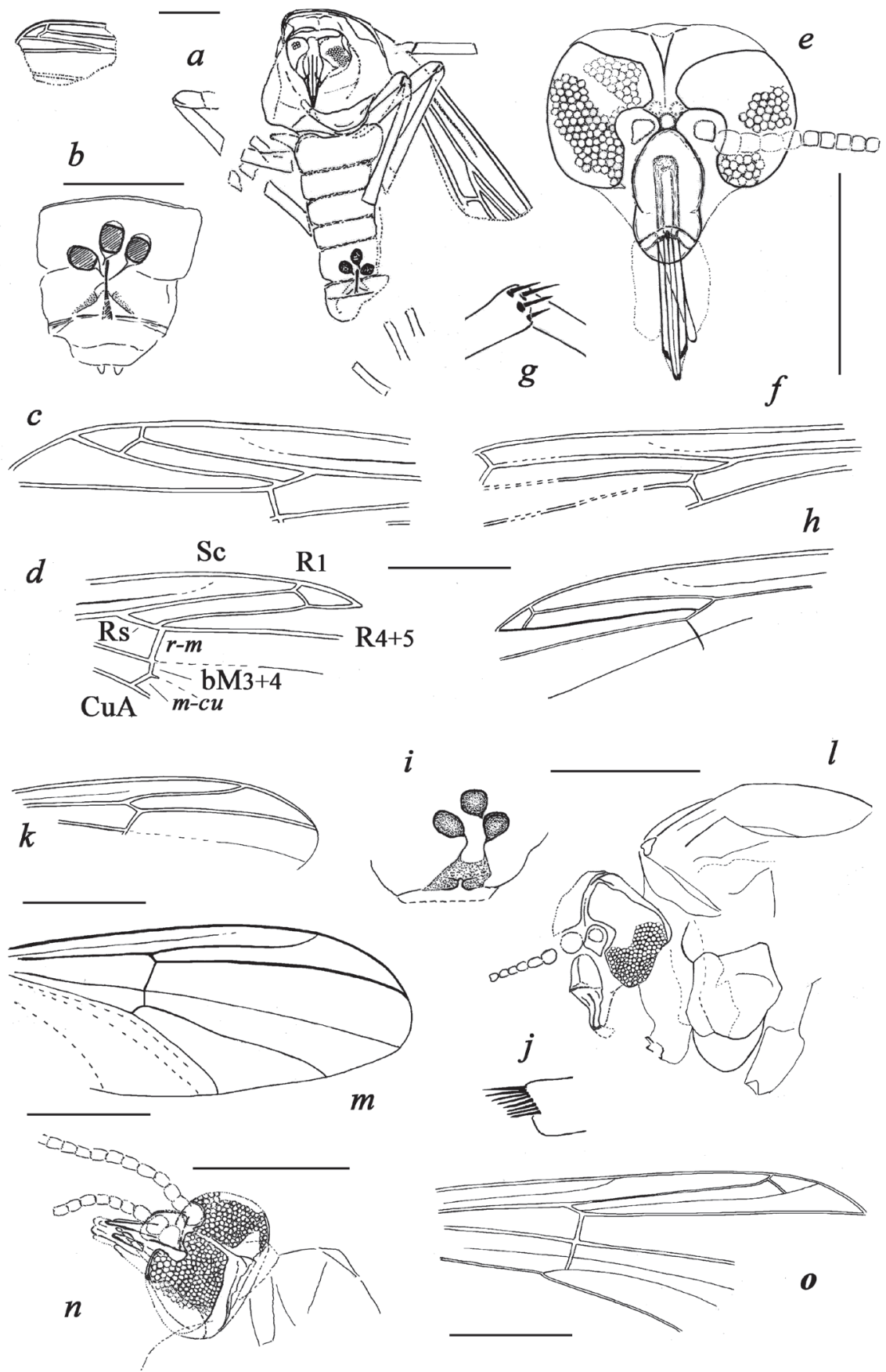

Figure I. a-h Cretaenne rasnicyni sp. n. a-d holotype (a total habitus $\mathbf{b}$ abdominal apex c, $\mathbf{d}$ wings) e-f paratype PIN 4270/2367 (head and wing) g-h paratype PIN 4270/2459 (apex of midtibia and wing) i-I Podonomius blepharis sp. $\mathrm{n}$., holotype (i abdominal apex $\mathbf{j}$ hind tibial apex $\mathbf{k}$ wing $\mathbf{I}$ head and thorax) m-n P. macromastix sp. n., holotype (wing and head) o Tanypodinae inc. sed., PIN 4270/2324; all from Shar Teg, $\mathrm{J}_{3}$ Scale bar $0.5 \mathrm{~mm}$ except for $\mathbf{g}$, j without scale. 
type genus of the subfamily, Aenne Ansorge, 1999 from the Late Triassic and Early Jurassic of Europe (Krzeminski and Jarzembowski 1999, Azar et al. 2008). In the new species from Shar Teg, the stem Rs is long without doubt but Sc is clear only to the level of the first Rs bifurcation, then sharply thins out and possibly does not terminate in $\mathrm{C}$, as seen in Cretaenne. We did not reexamine the type material of Aenne and Cretaenne, but according to the published data, Rs length can vary within species: in Aenne liasina Ansorge, 1999, the relatively long Rs is longer or shorter than $r-m$ (Ansorge 1999: figs 6-7), whereas the distal thinning of Sc is not recorded. Consequently, the new species is described here as a member of Cretaenne due to several features unknown for Aenne (described from isolated wings only), viz. a reduced hind tibial comb, the postnotum with a longitudinal groove, the structure of well-developed extended proboscis, and, probably, spurs on middle and hind tibia. Actually, biting mandibles were reported for the Mesozoic Aenne with reference to unpublished data of Cranston (Grimaldi and Engel 2005: 504).

\section{Subfamily Podonominae Thienemann \& Edwards, 1937}

\section{Genus Podonomius Kalugina, 1985}

http://species-id.net/wiki/Podonomius

Podonomius Kalugina and Kovalev 1985: 101. Type species Podonomius tugnuicus Kalugina and Kovalev 1985: 102.

The genus was described for six species from the Early and Middle Jurassic of Siberia, with only two species being attributed with certainty. Later, one more species from the Early Jurassic of Germany was tentatively included (Ansorge 1996). The specimens under description are assigned to this genus due to their broad head, large reniform eyes with dorsomedial projection, short thorax (no longer than its height), narrow scutellum, short postnotum, three rounded sclerotized spermathecae, and peculiarities of venation (vein $\mathrm{C}$ long, reaching $\mathrm{R}_{4+5}$ tip; Sc not terminating in wing margin; $\mathrm{R}_{2+3}$ absent; $\mathrm{R}_{1}$ long, not thickened distally in female; $\mathrm{R}_{4+5}$ straight or only slightly curved down distally; $\mathrm{bR}_{4+5}$ and $m$-cu inclined to long wing axis; $r-m, \mathrm{bM}_{3+4}$ and $m$-cu aligned; $r-m$ much longer than $\mathrm{bM}_{3+4}$; cell $b a$ and $b p$ not symmetrical; $m$-cu connecting $\mathrm{Cu}$ proximal to $r-m$; costal and radial veins, stem $\mathrm{M}$ and $\mathrm{CuA}, r-m, \mathrm{bM}_{3+4}$ and $m$-cu thickened, other veins very thin and pale; wings without spots).

We re-examined the type material of the six species described by Kalugina (1985) from Siberia (Fig. 2i) but did not examine ?P. tumidus Ansorge, 1996 from Grimmen. A postnotum without longitudinal median groove was recorded in the original diagnosis of Podonomius (for German species, such information was absent; Ansorge 1996). This feature is known only in Aphroteniinae and Podonominae and unknown in Tanypodinae and Buchonomyiinae (Brundin 1966, Murray and Fittkau 1989, Sæther 1989). Unfortunately it is impossible to see this important character in the new specimens, in particular, due to the lateral position of impressions. Pubescence and setae of their bodies are also not visible on any specimens described here. 

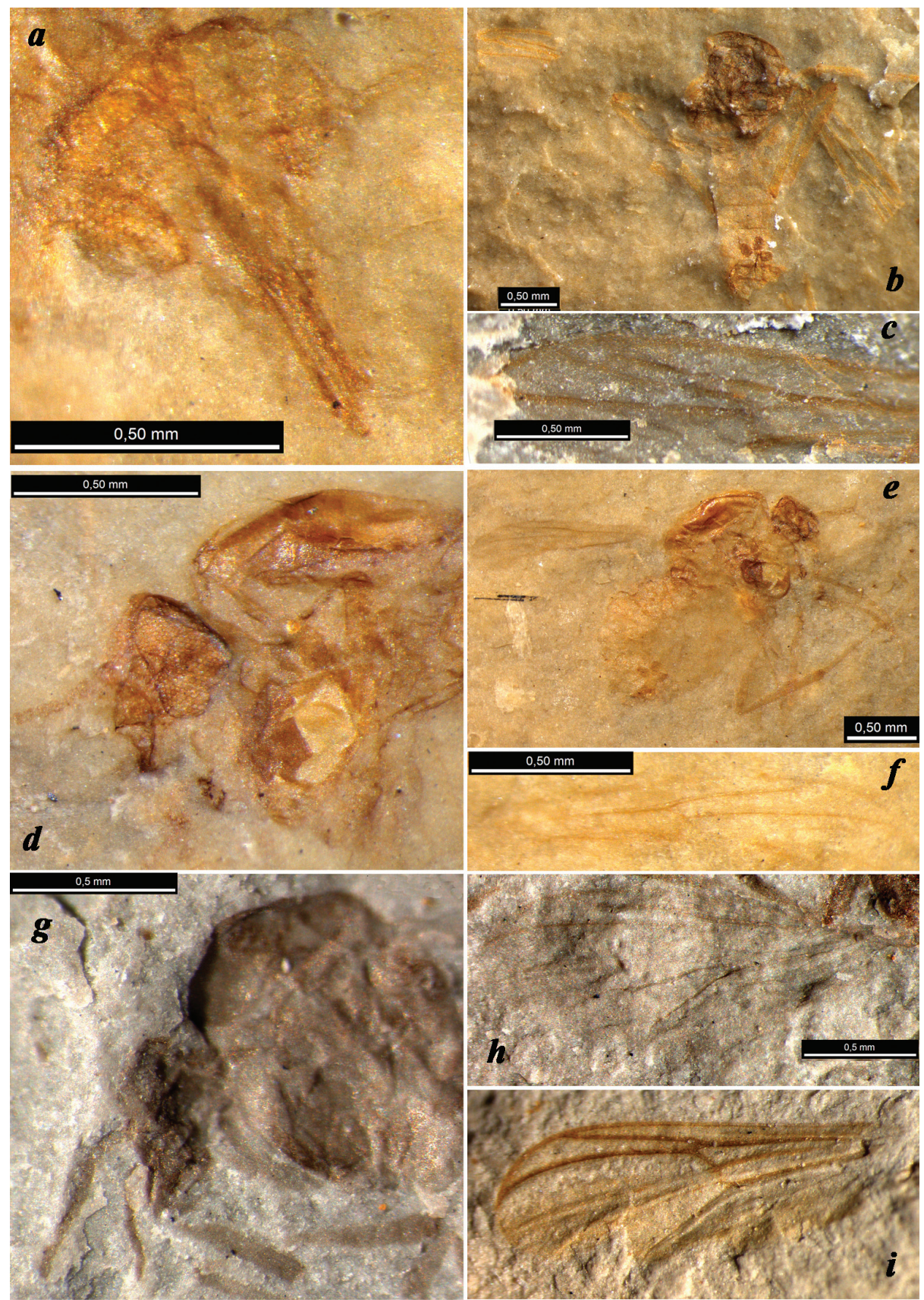

Figure 2. Jurassic Chironomidae: a-c Cretaenne rasnicyni sp. n. (a paratype PIN 4270/2367, female head under alcohol b-c holotype $\mathbf{b}$ female habitus, positive impression under alcohol $\mathbf{c}$ wing, negative impression) d-f Podonomius blepharis sp. n., holotype (d female head and thorax, negative impression under alcohol $\mathbf{e}$ female habitus, positive impression under alcohol $\mathbf{f}$ wing, negative impression under alcohol) g-h P. macromastix sp. n., holotype (female head and wing); all from Shar Teg, $\mathrm{J}_{3} \mathbf{i}$ holotype of ?P. rotundatus Kalugina, 1985, Kubekovo, $\mathrm{J}_{2}$. 


\section{Podonomius blepharis sp. $\mathrm{n}$.}

urn:lsid:zoobank.org:act:EE993F1F-6B84-4BA7-80B6-9905C90DA6B2

http://species-id.net/wiki/Podonomius_blepharis

Etymology. From Greek "blepharis" for eyelash, after the pattern of the tibial comb.

Material examined. Holotype: part and counterpart of well-preserved female PIN 4270/2357 \pm , SW Mongolia, Shar Teg (443/1); Late Jurassic.

Diagnosis. The new species is distinguished by its small size (wing length $1.4 \mathrm{~mm}$ ), well-developed elongate proboscis, weakly convex scutum without a hump, wing with broad cell $c$, and pale legs with darker junction of femur with trochanter and tibia, and with combs of dark closely-spaced spiniform setae at tibial apices.

Description. Female (Figs 1i-l, 2d-f). Measurements (mm): Total length 2.0; thorax length 0.8 , height 0.9 ; abdomen length 1.0 ; wing length 1.4 . Total length / wing length 1.4. Coloration. Head and thorax dark, abdomen lighter, legs pale with darker junction of femur with trochanter and tibia, with darker apices of tibiae. Head no less than $600 \mu \mathrm{m}$ wide, no less than $550 \mu \mathrm{m}$ high with proboscis, $380 \mu \mathrm{m}$ high to lower eye margin. Eyes large, with wide dorsomedial extension, looking narrowly separated by ca. $30 \mu \mathrm{m}$. Facets equal. Coronal triangle ca. $100 \mu \mathrm{m}$ high, coronal suture clear near upper eye margin. Scape $90 \mu \mathrm{m}$, pedicel $45 \mu \mathrm{m}$ in diameter; proximal flagellomeres short-oval to rounded, ca. $35 \mu \mathrm{m}$ wide and 40-50 $\mu \mathrm{m}$ long. Clypeus ca. $100 \mu \mathrm{m}$ wide, ca. $150 \mu \mathrm{m}$ high, possibly with longitudinal groove. Proboscis well-developed, elongate, sclerotized at least in distal part, ca. $200 \mu \mathrm{m}$ long (projecting distally of clypeus for no less than 120 $\mu \mathrm{m})$, ca. $30 \mu \mathrm{m}$ wide at visible apex. Thorax. Scutum weakly, evenly convex, without hump or tubercle. Scutellum ca. $150 \mu \mathrm{m}$ long, not projecting. Postnotum ca. $200 \mu \mathrm{m}$ long. Wing. Vein $\mathrm{C}$ probably not produced beyond $\mathrm{R}_{4+5} ;$ cell $c$ at $r-m$ level subequal to cell $r_{1}$, which only slightly narrower than $r_{5}$ cell at level of $\mathrm{R}_{1}$ tip; $\mathrm{R}_{1}$ approximately $2 / 3$ as long as almost straight $\mathrm{R}_{4+5} ; r-m$ inclined to $M$. All veins mentioned strong, coloured. Legs. Measurements $(\mu \mathrm{m}) \cdot \mathrm{p}_{1}\left(\right.$ ?): $\mathrm{ta}_{1} 380, \mathrm{ta}_{2-5} \mathrm{ca} .405 ; \mathrm{p}_{2}$ : fe 700, ti 680; $\mathrm{p}_{3}$ : fe 560, ti 680, ta $_{1}$ ca. $500, \mathrm{ta}_{2-5}$ ca. $650, \mathrm{LR}_{3}$ ca. 0.75 . Femora maximum ca. 110-120 $\mu \mathrm{m}$ wide, with thin sclerotized ridge ventrally near apex. Tibiae ca. $80 \mu \mathrm{m}$ wide. Apices of mid-, hind tibiae with combs of dark closely-spaced spiniform setae ca. $50 \mu \mathrm{m}$ long; in midtibial comb, no less than 10 setae, in hind tibial comb, 8 setae. Spurs not observed. Abdomen. Segments III-VII: tergites 150-180 $\mu \mathrm{m}$ long. Three large subequal oval moderately sclerotized spermathecae $100 \mu \mathrm{m}$ long, ca. $80 \mu \mathrm{m}$ wide, with necks (probably, long), in compact group. Sternite VIII with posteromedian sclerotized plate, its posterior margin bilobate; probable gonocoxites VIII (gonacoxapodemes?) visible as moderately sclerotized small oval lobes approximating each other. Cerci not visible.

Remarks. The new species is similar to P. splendidus Kalugina, 1985 ( $\mathrm{J}_{1 / 2}$, Novospasskoye, Transbaikalia) in its venation (C length, ratio $\mathrm{R}_{1} / \mathrm{R}_{4+5}$ ), colour pattern of legs and elongated mouthparts, which are visible on paratype PIN 3000/1857 (in the other type specimens of Podonomius from Siberia, the mouthparts are not visible due to the state of preservation). Podonomius blepharis sp. n. differs from P. splendidus in broader cell $c$ and smaller size. As for tibial combs, Kalugina noted (1985) that in P. tugnuicus 
and $P$. splendidus the tibial apices are darkened but without mentioning combs. According to our re-examination of the type material of $P$. splendidus, the hind tibia has a reduced comb consisting of a row of separate dark points, which may be minute setae or possibly bases of missing long bristles (these seem to be visible near the tibial apex in the holotype). In the latter case, a well-developed tibial comb is not unique for $P$. blepharis.

\section{Podonomius macromastix sp. $\mathrm{n}$.}

urn:lsid:zoobank.org:act:AD0202E9-83D8-4462-B354-5D9697CA7485

http://species-id.net/wiki/Podonomius_macromastix

Etymology. From Greek "makros" for long and "mastix" for whip, after the long antenna.

Material examined. Holotype: part and counterpart of well-preserved female PIN 4270/2314 , SW Mongolia, Shar Teg (423/6); Late Jurassic.

Diagnosis. The new species is distinguished by its small size (wing length 1.9), well-developed elongate proboscis, strongly convex scutum with a hump, comparatively long wings with $\mathrm{R}_{1}$ with arched tip and broad cell $r_{5}$, and pale legs with darker junction of femur with trochanter and tibia.

Description. Female (Figs $1 \mathrm{~m}-\mathrm{n}, 2 \mathrm{~g}-\mathrm{h}$ ). Measurements $(\mathrm{mm})$ : Total length 2.0; thorax length 0.7 , height 0.9 ; wing length 1.9 , width 0.8 ; abdomen length 1.1 . Total length / wing length ca. 1.05. Coloration pattern as in P. blepharis sp. n. Head $480 \mu \mathrm{m}$ wide, no less than $600 \mu \mathrm{m}$ high with proboscis, $380 \mu \mathrm{m}$ high to lower eye margin. Eyes large, with wide dorsomedial extension, narrowly separated by ca. $30 \mu \mathrm{m}$. Facets slightly increasing to lower eye parts. Coronal triangle ca. $50 \mu \mathrm{m}$ high, coronal suture ca. $80 \mu \mathrm{m}$ high. Antenna no less than $600 \mu \mathrm{m}$. Scape ca. $80 \mu \mathrm{m}$, pedicel ca. 60 $\mu \mathrm{m}$ in diameter; at least 12 flagellomeres, ca. $35 \mu \mathrm{m}$ wide (proximal 6 flagellomeres moniliform, 40-45 $\mu \mathrm{m}$ long; others cylindrical, 50-70 $\mu \mathrm{m}$ long). Clypeus ca. 130 $\mu \mathrm{m}$ wide, ca. $150 \mu \mathrm{m}$ high. Proboscis well-developed, elongated, tapering, ca. $180 \mu \mathrm{m}$ long (about $1 / 3$ of head height), ca. $70 \mu \mathrm{m}$ wide at visible apex, with pair of separate sclerotized blades. Thorax. Scutum strongly convex, with hump before midlength, 700 $\mu \mathrm{m}$ long. Postnotum ca. $200 \mu \mathrm{m}$ long. Wing much longer than abdomen. Vein C only slightly produced beyond $\mathrm{R}_{4+5}$, not reaching wing tip; cell $c$ at $r-m$ level broader than cell $r_{1}$, which is almost half as wide as cell $r_{5}$ at $\mathrm{R}_{1}$ tip level; $\mathrm{R}_{1}$ with arched tip, 2/3 as long as slightly curved down distally $\mathrm{R}_{4+5} ; r-m$ slightly inclined, $\mathrm{bM}_{3+4}$ almost perpendicular to M. Legs poorly visible. Measurements $(\mu \mathrm{m}) \cdot \mathrm{p}_{2}$ (?): fe ca. 550, ti ca. 700, ta $_{1-5}$ ca. 700; $\mathrm{p}_{3}$ (?): ti ca. $870, \mathrm{ta}_{1-5}>800$. Hind femora ca. $110 \mu \mathrm{m}$ wide; hind tibiae 70-80 $\mu \mathrm{m}$ wide at apex, with sclerotized apical traces, possibly of setae bases. Abdomen with three large unequal short-oval sclerotized spermathecae 60-90 $\mu \mathrm{m}$ long, 50-60 $\mu \mathrm{m}$ wide, with necks, in compact group. Cerci ca. $40 \mu \mathrm{m}$ long.

Remarks. The new species is similar to ?P. rotundatus Kalugina, $1985\left(\mathrm{~J}_{2}\right.$, Kubekovo, South Siberia, Fig. 2i) in its venation (length of $C, R_{1} / R_{4+5}$ ratio, cells $r_{1} / r_{5}$ ratio) and size, but is distinguished by the arched tip of $\mathrm{R}_{1}$. The new species differs from $P$. blepharis sp. $\mathrm{n}$. in the longer wings with broader cell $\mathrm{r}_{5}$ and thoracic shape. 


\section{? Podonomius robustus sp. $\mathrm{n}$.}

urn:lsid:zoobank.org:act:189103E1-9FA9-45DE-A4E4-52EF0CE68913

http://species-id.net/wiki/Podonomius_robustus

Etymology. From Latin "robustus" for stout, after the total habitus.

Material examined. Holotype: Part and counterpart of partly preserved female PIN 4270/2254 \pm , SW Mongolia, Shar Teg (443/1); Late Jurassic.

Diagnosis. The new species is distinguished by its medium size (wing length 3.7 $\mathrm{mm}$ ), well-developed, strongly elongate proboscis, wing with $\mathrm{C}$ produced beyond $\mathrm{R}_{4+5}$ and reaching wing tip, strongly sclerotized abdomen and legs, and one spermatheca situated proximally of other two.

Description. Female (Fig. 3). Measurements (mm): Total length 4.1; thorax length 1.5, width ca. 1.0; abdomen length 2.9; wing length 3.7. Total length / wing length 1.1. Coloration. Head, thorax, abdomen, legs uniformly dark. Head $700 \mu$ m wide, no less than $1100 \mu \mathrm{m}$ high with proboscis, $550 \mu \mathrm{m}$ high to lower eye margin. Eyes large, with wide dorsomedial extension, well-separated by ca. $100 \mu \mathrm{m}$. Facets equal. Frontal strip between eye extensions dark-coloured, long, sclerotized. Coronal triangle ca. 100 $\mu \mathrm{m}$ high, coronal suture ca. $70 \mu \mathrm{m}$ high. Scape ca. $125 \mu \mathrm{m}$, pedicel ca. $40 \mu \mathrm{m}$ in diameter. Clypeus ca. $200 \mu \mathrm{m}$ high, ca. $150 \mu \mathrm{m}$ wide. Proboscis very long, strong (longer than remainder of head), tapering, ca. $550 \mu \mathrm{m}$ long, ca. $80 \mu \mathrm{m}$ wide at (visible) apex; apical part with pair of sclerotized blades. Probable palpi no less than $400 \mu \mathrm{m}$ long, two visible segments elongate, cylindrical, ca. $150 \mu \mathrm{m}$ long, ca. $30 \mu \mathrm{m}$ wide. Thorax. Scutum $900 \mu \mathrm{m}$ long; postnotum ca. $250 \mu \mathrm{m}$ long. Wing clearly longer than abdomen. Vein $\mathrm{C}$ produced beyond $\mathrm{R}_{4+5}$ (costal extension ca. $200 \mu \mathrm{m}$ ), reaching wing tip; cell $c$ at $r$ - $m$ level broader than cell $r_{1} ;$ cell $r_{5}$ at $\mathrm{R}_{1}$ tip level almost twice as wide as cell $r_{1} ; \mathrm{R}_{1}$ straight, $2 / 3$ as long as $\mathrm{R}_{4+5}$. Vein $\mathrm{C}$, radial veins, $\mathrm{M}, r-m$ strong and coloured; other veins thin, pale. Legs. Mid- and hind femora ca. $180 \mu \mathrm{m}$ wide; tibiae $100-120 \mu \mathrm{m}$ wide near apex. Apex of mid- or hind tibia with traces of at least 5 spiniform setae. Abdomen. Segments II-VIII 250-300 $\mu \mathrm{m}$ long, 800-900 $\mu \mathrm{m}$ wide. Three rounded sclerotized spermathecae 70-90 $\mu \mathrm{m}$ in diameter, with long necks, largest spermatheca situated proximally of other two. Gonapophysis IX distinctly visible, sclerotized, with notum ca. $200 \mu \mathrm{m}$ long and rami ca. $50 \mu \mathrm{m}$ long. Posterior margin of sternite VIII bilobate: probable gonocoxites VIII (gonacoxapodemes?) visible distal to spermathecae. Cerci distinct, elongate-oval, $150 \mu \mathrm{m}$ long, ca. $70 \mu \mathrm{m}$ wide.

Remarks. Adults of this new species are the largest among Podonomius (wing length is similar only in ?P. simplex Kalugina, 1985 ( $\mathrm{J}_{2}$, Kubekovo, South Siberia), but in the Siberian species $\mathrm{R}_{1}$ is curved up distally). ?Podonomius robustus sp. n. differs from other species from Shar Teg also in the longer costal extension. Such a long costa extending to the wing tip is an important plesiomorphic character (Brundin 1976) and may be a character of generic value. Thus, the new species is only tentatively placed in Podonomius. 
$a$
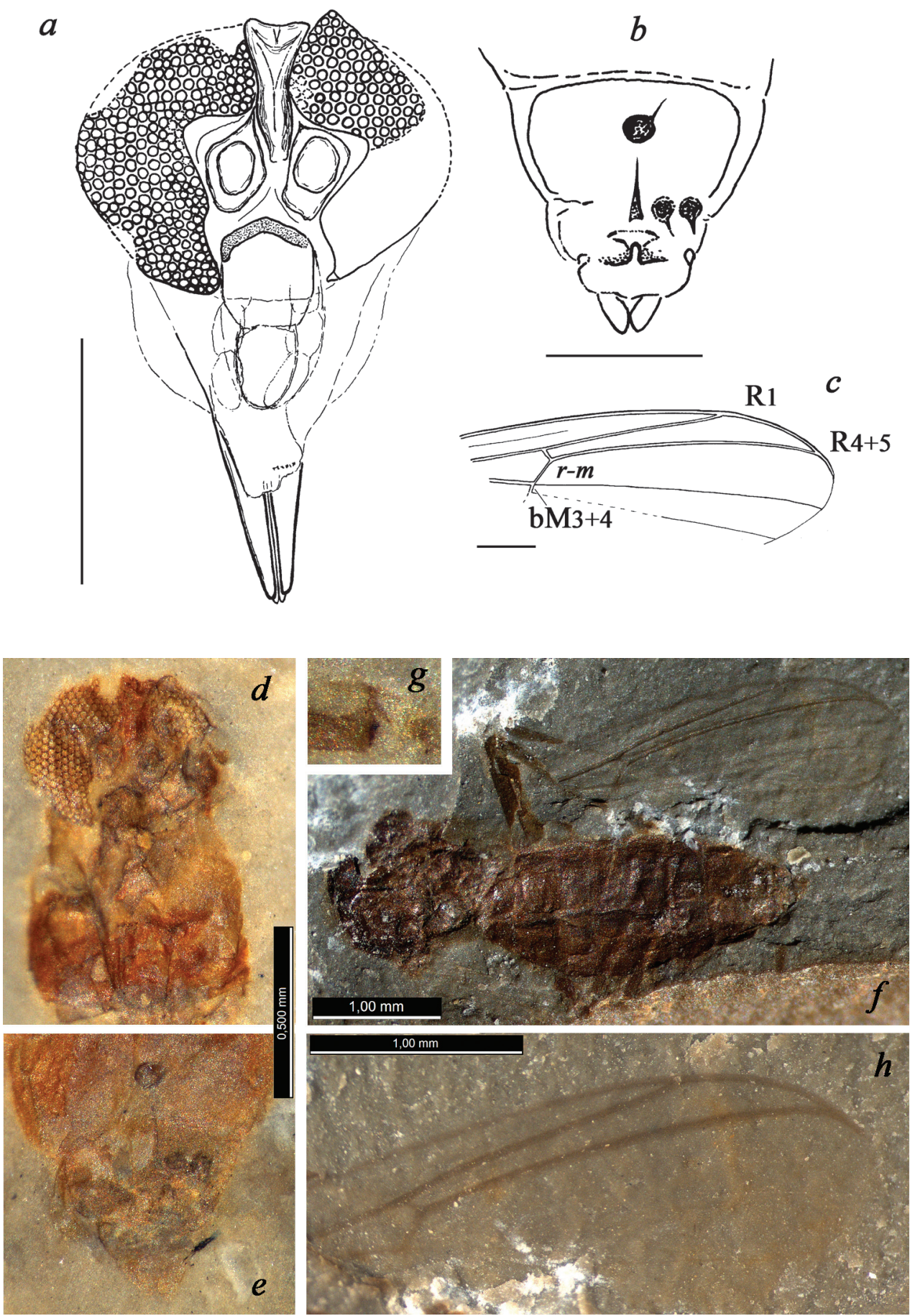

Figure 3. ?Podonomius robustus sp. n., holotype (a, $\mathbf{d}$ head, positive impression $\mathbf{b}$, e abdominal apex, negative impression $\mathbf{c}, \mathbf{h}$ wing, negative impression $\mathbf{f}$ female habitus, negative impression $\mathbf{g}$ apex of hind tibia, positive impression; all photos made under alcohol except for $\mathbf{f}$ ); Shar Teg, $\mathrm{J}_{3}$ S Scale bar $0.5 \mathrm{~mm}$ 


\section{Subfamily Tanypodinae Skuze, 1889}

Among fifty adult chironomids from Shar Teg, only two incomplete females (PIN 4270/2324 , 4270/2431) and one male (PIN 4270/2384) can be determined as members of this subfamily (all from the same $443 / 1$ outcrop) due to the typical venation on partly preserved wings (Fig. 1o). The poor state of their preservation does not allow us to place the specimens within a genus.

\section{Discussion}

The four new species of Chironomidae described in this paper are characterized by the elongate proboscis with well-developed (probably sclerotized) mandibles and/or maxillae. To date, a well-developed piercing proboscis has been described only in two recent and no less than four extinct genera of the Chironomidae (Azar et al. 2008). Among the recent Chironomidae, strongly elongate mouthparts are known also in some Orthocladiinae, namely, in both sexes of the North American species Pseudorthocladius macrostomus Soponis, 1980 and Rhinocladius Edwards, 1931 (all three species; distributed in South America and Australia). Their proboscis, superficially resembling that of a mosquito, is formed entirely of the extremely elongated labellae, devoid of stylets and presumably used for sipping nectar, not for piercing (Edwards 1931, Freeman 1961, Soponis 1980). Possibly, a poorly described species Camptocladius nigripectus Bigot 1888 has a similar type of the proboscis (Edwards 1931).

The proboscises of Cretaenne rasnicyni sp. n. and ?Podonomius robustus sp. n. are much longer than in any other fossil Chironomidae described to date (possibly except for an undeterminable culicomorphan from the Triassic Cow Branch Formation; Blagoderov et al. 2007). Among the Chironomoidea, similar strongly elongate mouthparts are known in a number of recent species in many genera of Ceratopogonidae belonging to different lineages of this family, such as Culicoides Latreille, 1809, Echinohelea Macfie, 1940, Atrichopogon Kieffer, 1906, Forcipomyia Meigen, 1818, Leptoconops Skuse, 1889, as well as in extinct species such as the Lower Cretaceous Protoculicoides skalskii Szadziewski, Arillo, 1998, P. punctus Borkent, 2000, and the Upper Cretaceous Culicoides filipalpus Remm, 1976 (e.g. Borkent 2000, Borkent et al. 2009). In nearly all Ceratopogonidae with such mouthparts, females are either insectivorous predators, or blood-suckers on vertebrates, or haemolymph-suckers on insects. However, haemolymph-sucking is restricted to Forcipomyiinae and considered derived feeding mode which appeared in the Cenozoic (Borkent 2000). Nectar-feeding ceratopogonids usually have the stylets more or less reduced, but Forcipomyia (F) brevipennis (Macquart, 1826) considered nectarophagous retains the sclerotized, distinctly toothed mandibles subequal in size to piercing mandibles of its insectivorous congeners (Glukhova 1981). By analogy with Ceratopogonidae we assume that the females of the new chironomid species were entomophagous or haematophagous but secondary nectarophagy cannot be excluded. It is impossible to argue for one of these feeding types, because the fine details of the mouthparts are not discernible in our fossils. 
In the general appearance (very long and strong proboscis, body size, shape and proportions; pattern and degree of sclerotization, e.g. strongly sclerotized abdomen and legs) ?P. robustus differs from "typical" Chironomidae as well as from other species assigned to the genus Podonomius and resembles some "robust" Ceratopogonidae, especially many Palpomyiini, but this advanced tribe is unknown from the Mesozoic (Szadziewski 1996). Unfortunately, the posterior part of the wing is not visible in the holotype of ?P. robustus, as well as in the holotype of P. blepharis sp. n., and the presence of a forked $\mathrm{M}_{1+2}$ (characteristic of Ceratopogonidae) cannot be excluded. Thus, the position of these two species seems to be somewhat uncertain. Similar female wings bare of macrotrichia, with well-developed single radial cell, costal ratio more than 0.9 and vein $\mathrm{C}$ produced beyond $\mathrm{R}_{4+5}$ and almost reaching wing tip, are known in several Cretaceous species of the ceratopogonid genus Protoculicoides Boesel, 1937, such as P. schleei (Szadziewski, 1996) and P. unus Borkent, 2000 from Lebanese amber (Borkent 2000).

However, in the holotype of ?P. robustus the partly visible transverse vein under $r-m$ is undoubtedly coloured, that is not recorded for the basal part of vein $M_{2}$ in ceratopogonid wing, but typical for $\mathrm{bM}_{3+4}$ in podonomine wing (Figs $2 \mathrm{~h}-\mathrm{i}$ ). In addition, the venation pattern of the anterior part of the wing is more similar to Podonominae than to Ceratopogonidae (vein $\mathrm{R}_{1}$ long, cell $\mathrm{r}_{1}$ long and not narrow) and the vertex of $P$. blepharis as well as ?P. robustus possesses a coronal suture, which is a feature of the Chironomidae, absent in Ceratopogonidae (Sæther 2000). Moreover, ?P. robustus has a well-developed elongate notum of gonapophysis IX, whereas its absence has been considered as a synapomorphy of the Ceratopogonidae (Sæther 2000), and only some early lineages of Ceratopogonidae have a differently-shaped, short squat notum (vaginal apodeme in Borkent et al. 1987). So we exclude ceratopogonid affinity for both discussed species in spite of the incomplete state of preservation and the strong resemblance to insectivorous predatory or bloodsucking ceratopogonids in the general appearance and consider them as members of Podonominae.

The subfamily Podonominae is shown to be a dominant one in specimen abundance and diversity in the Jurassic deposits of Siberia (Kalugina and Kovalev 1985). No relevant data are available for the other regions. Kalugina stressed the difficulties in differentiation of the Mesozoic Podonominae and Tanypodinae and suggested that often it was possible to classify new taxa with certainty only as members of Tanypodoinae (Tanypodinae + Aphroteniinae + Podonominae) (Kalugina and Kovalev 1985: 82). However, she assigned new genera to subfamilies and explained her choice at every turn. At the same time, Kalugina assumed that some taxa she described in the Podonominae might actually belong to the Tanypodinae, considering that these two subfamilies were less clearly distinguished morphologically in the Jurassic.

Recently, Veltz et al. (2007) have concluded that subfamily identification of Jurassic Chironomidae is impossible and all Podonominae described by Kalugina are Chironomidae incertae sedis. Their only argument was rather methodical: Veltz and coauthors found it impossible to assign the different life stages to the same species as well as different species known only as pupae, to the same genus. Veltz and coauthors did not discuss the arguments proposed by Kalugina, e.g. that the larvae with translucent thoracic horns and 
pupae with translucent male genitalia were found among the numerous Jurassic impressions of Oryctochlus Kalugina, 1985, so the association of larvae with pupae was made with certainty and those of pupae and imago, with some doubts. Kalugina compared every life stage of Oryctochlus with those of recent Trichotanypus Kieffer, 1906 and drew a conclusion about an undoubted affinity of these two genera of Podonominae (e.g. in pupae of both genera, segment VIII is deeply emarginated posteriorly, which is remarkably similar to segment IX in shape and segment IX with 3 lateral setae, 2 of which are close together in mid-section). According to the time-calibrated molecular data (Cranston et al. 2010), Trichotanypus is one of the oldest genera of the subfamily, which split from Parochlini in the Early Cretaceous. The French authors did not discuss substantially any genus described by Kalugina. However, they considered that Podonominae may not be recorded in the Mesozoic (Azar et al. 2008), but that hardly can be true. A transfer of Libanochlites Brundin, 1976 (K $\mathrm{K}_{1}$, Lebanese amber) from Podonominae to Tanypodinae made by these authors based on their new data was not supported by other specialists (Cranston et al. 2010).

\section{Acknowledgements}

We are deeply indebted to Dmitry Shcherbakov (Moscow) for valuable discussions. We are grateful to Art Borkent (Canada) and Peter Cranston (Australia) for insightful comments on the manuscript and for improving the English. The research was partly supported by the programme of the Presidium of Russian Academy of Sciences "Biosphere origin and evolution of geobiological systems".

\section{References}

Ansorge J (1996) Insekten aus dem oberen Lias von Grimmen (Vorpommern, Norddeutschland). Neue Palaontologische Abhandlungen 2: 1-132.

Ansorge J (1999) Aenne liasina gen. et sp. n. - the most primitive non biting midge (Diptera: Chironomidae: Aenneinae subfam. n.) from the Lower Jurassic of Germany. Polskie Pismo Entomologiczne 68: 431-443.

Azar D, Veltz I, Nel A (2008) Mandibulate chironomids: primitive or derived? (Diptera: Chironomidae). Systematic Entomology 33: 688-699. doi: 10.1111/j.1365-3113.2008.00438.x

Blagoderov V, Grimaldi DA, Fraser N (2007) How time flies for flies: diverse Diptera from the Triassic of Virginia and early radiation of the order. American Museum Novitates 3572: 1-39. doi: 10.1206/0003-0082(2007)509[1:HTFFFD]2.0.CO;2

Borkent A, Wirth WW, Dyce AL (1987) The newly discovered male of Austroconops (Ceratopogonidae: Diptera) with a discussion of the phylogeny of the basal lineages of the Ceratopogonidae. Proceedings of Entomological Society of Washington, 89: 587-606.

Borkent A (2000) Biting midges (Ceratopogonidae: Diptera) from Lower Cretaceous Lebanese amber with a discussion of the diversity and patterns found in other ambers. In: Grimaldi 
D (Ed) Studies on Fossils in Amber, with Particular Reference to the Cretaceous of New Jersey. Backhuys Publishers, Leiden, 355-451.

Borkent A, Spinelli GR, Grogan WL Jr. (2009) Ceratopogonidae (biting midges, purrujas). In: Brown BV (Ed) Manual of Central American Diptera, Volume 1. National Research Council Research Press, Ottawa, 407-435.

Brundin L (1966) Transantarctic relationships and their significance, as evidenced by chironomid midges with a monograph of the subfamilies Podonominae and Aphroteniinae and the Austral Hertagyiae. Kunglica Svenska Vetenskapsakademiens Handlingar 11: 1- 472.

Brundin L (1976) A Neocomian chironomid and Podonominae-Aphroteniinae (Diptera) in the light of phylogenetics and biogeography. Zoologica Scripta 5: 139-160.

Cranston PS, Edward DHD, Colless DH (1987) Archaeochlus Brundin: a midge out of time (Diptera: Chironomidae). Systematic Entomology 12: 313-334. doi: 10.1111/j.13653113.1987.tb00204.x

Cranston PS, Edward DHD, Cook LG (2002) New status, species, distribution records and phylogeny for Australian mandibulate Chironomidae. Australian Journal of Entomology 41: 357-366. doi: 10.1046/j.1440-6055.2002.00304.x

Cranston PS, Hardy NB, Morse GE, Puslednik L, McCluen SR (2010) When molecules and morphology concur: the "Gondwanan" midges (Diptera: Chironomidae). Systematic Entomology 35: 636-648. doi: 10.1111/j.1365-3113.2010.00531.x

Downes JA, Colless DH (1967) Mouthparts of the biting and blood-sucking type in Tanyderidae and Chironomidae. Nature 214: 1355-1356. doi: 10.1038/2141355a0

Edwards FW (1931) Chironomidae. Diptera of Patagonia and South Chile 2(5): 233-331.

Freeman P (1961) The Chironomidae (Diptera) of Australia. Australian Journal of Zoology 9(4): 611-737. doi: 10.1071/ZO9610611

Glukhova VM (1981) A comparative morphological review of the mouthparts of the females and the males in the subfamilies Dasyheleinae and Forcipomyiinae (Diptera, Ceratopogonidae). Entomologicheskoe Obozrenie 60(1): 62-76 [in Russian; English translation: Entomological Review 60(1): 59-72]

Grimaldi DA, Engel M (2005) Evolution of the Insects. Cambridge University Press: 755 pp.

Gubin YM, Sinitza SM (1996) Shar Teg: a unique Mesozoic locality of Asia. Museum of Northern Arizona Bulletin 60: 311-318.

Jell PA, Duncan PM (1986) Invertebrates, mainly insects, from the freshwater, Lower Cretaceous, Koonwarra Fossil Bed (Korumburra Group), South Gippsland, Victoria. Memoir of the Association of Australasian Palaeontologists 3: 111-205.

Kalugina NS (1992) Psychodomorph dipterans from the Jurassic of the Mongolian Altai (Diptera: Tanyderidae, Eoptychopteridae). Paleontologicheskii Zhurnal 3: 110-113 [in Russian; translated in Paleontological Journal 26(3): 142-146].

Kalugina NS (1993) Chaoborids and midges from the Mesozoic of Eastern Transbaikalia (Diptera: Chaoboridae and Chironomidae). Trudy of Paleontological Institute (Moscow) 252: 117-139. [in Russian]

Kalugina NS, Kovalev VG (1985) Jurassic Diptera of Siberia. Moscow: Nauka: 198 pp. [In Russian] 
Krzeminski W, Jarzembowski E (1999) Aenne triassica sp.n., the oldest representative of the family Chironomidae (Insecta: Diptera). Polskie Pismo Entomologiczne 68: 445-449.

Lukashevich ED (1996) Mesozoic Dixidae (Insecta: Diptera) and systematic position of Dixamima Rohdendorf, 1964 and Rhaetomyia Rohdendorf, 1962. Paleontologicheskii Zhurnal 1: 48-53 [in Russian; translated in Paleontological Journal 30(1): 45-51].

Lukashevich ED (2009) Limoniidae (Diptera) in the Upper Jurassic of Shar Teg, Mongolia. Zoosymposia 3: 131-154.

Lukashevich ED (in press) New Nematocera (Insecta: Diptera) from the Late Jurassic of Mongolia. Paleontologicheskii Zhurnal.

Murray DA, Fittkau EJ (1989) The adult males of Tanypodinae (Diptera: Chironomidae) of Holarctic region - Keys and diagnoses. In: Wiederholm T. (Ed) Chironomidae of Holarctic region. Keys and diagnoses. Part 3. Adult males. Entomologica Scandinavica Supplement 34: 37-123.

Rasnitsyn AP, Quicke LJ (2002) History of Insects. Kluwer Academic Publishers, Dordrecht, Boston, London, 517 pp. doi: 10.1007/0-306-47577-4

Sæther OA (1980) Glossary of chironomid morphology terminology (Diptera: Chironomidae). Entomologica Scandinavica Supplement 14: 1-52.

Sæther OA (1989) The adult males of Buchonomyiinae (Diptera: Chironomidae) of Holarctic region - Diagnoses. In: Wiederholm T. (Ed) Chironomidae of Holarctic region. Keys and diagnoses. Part 3. Adult males. Entomologica Scandinavica Supplement 34: 125-127.

Sæther OA (2000) Phylogeny of Culicomorpha (Diptera). Systematic Entomology 25: 223234.

Soponis AR (1980) Pseudorthocladius macrostomus, a new species of Chironomidae (Diptera) with a long proboscis. The Florida Entomologist 68: 485-490. doi: 10.2307/3494533

Szadziewski R (1996) Biting midges from Lower Cretaceous amber of Lebanon and Upper Cretaceous Siberian amber of Taimyr (Diptera, Ceratopogonidae). Studia Dipterologica 3: 23-86.

Shcherbakov DE, Lukashevich ED, Blagoderov VA (1995) Triassic Diptera and initial radiation of the order. International Journal of Dipterology 6(2): 75-115.

Veltz I, Azar D, Nel A (2007) New chironomid flies in Early Cretaceous Lebanese amber (Diptera: Chironomidae). African Invertebrates 48(1): 169-191.

Wootton RJ, Ennos AR (1989) The implications of function on the origin and homologies of the dipterous wing. Systematic Entomology 14: 507-520. doi: 10.1111/j.13653113.1989.tb00300.x 